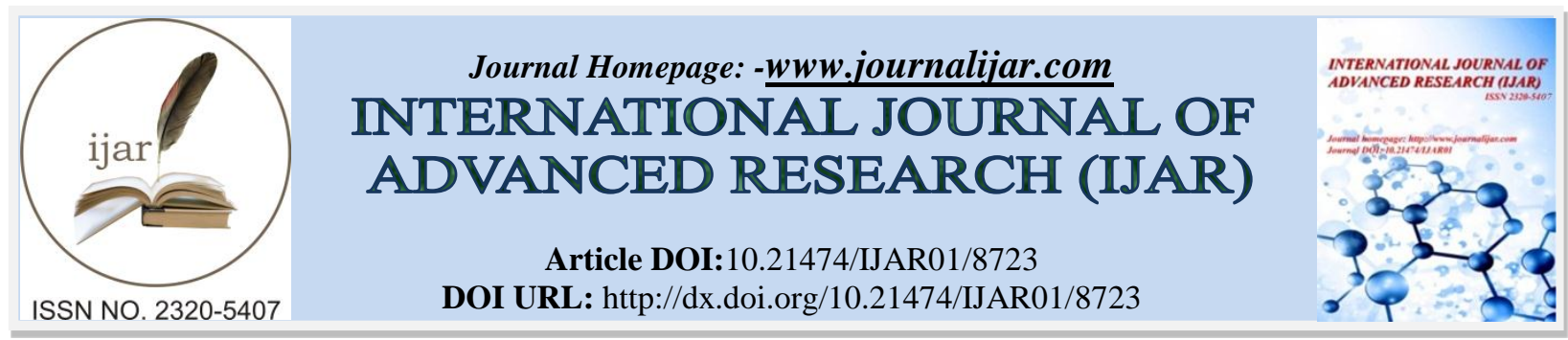

RESEARCH ARTICLE

\title{
EFFECT OF FOOT REFLEXOLOGY ON LACTATION- A LITERATURE REVIEW.
}

\section{Ms. Nikita Machhi ${ }^{1}$ and Ms. Anjali Tiwari ${ }^{2}$.}

1. M.Sc. Nursing, Manikaka Topawala Institute of Nursing, CHARUSAT, Gujarat.

2. Assistant Professor and HOD, Dept. of Obstetrics \& Gynaecological Nursing, Manikaka Topawala Institute of Nursing, CHARUSAT, Gujarat.

\section{Manuscript Info}

Manuscript History

Received: 17 January 2019

Final Accepted: 19 February 2019

Published: March 2019

Key words:-

lactation, foot reflexology, postnatal women.

\begin{abstract}
The aim of researcher is to evaluate the effect of foot reflexology on lactation among postnatal women. Lactation refers to the formation of milk in the breasts during the period following childbirth. Breast feeding is a natural human activity. To have the full benefit of breastfeeding, the WHO recommended exclusive breastfeeding for at least six months of life and supplemented breastfeeding for at least one year. The most common causes of lactation failures are stress, fatigue, anxiety, anaesthesia, strong sedation, prolong labor, surgical intervention, placenta retention etc. There are many Pharmacological and non- pharmacological methods to improve lactation some of which includes maternal and infant positioning, milk transfer, frequency of feeds and alternative therapies such as foot reflexology, acupuncture, herbal medicines, relaxation therapy, aroma therapy and homeopathy. Non pharmacological treatments have a slower effect but it provides effective care. Foot reflexology has shown evidence of effect on lactation in some studies. But such studies are not much in number when searched to be done in the researcher's area of interest, because it helps to increase milk supply and facilitating a more rapid 'let down' for milk flow. Hence, in an attempt to conduct this research, significant information was sought by the researchers from literature review about foot reflexology on Lactation.
\end{abstract}

Copy Right, IJAR, 2019,. All rights reserved.

\section{Introduction:-}

Lactation is the process of milk production. The hormone oxytocin begins the lactation process and it cause uterine contractions after birth. Prolactin hormone stimulates the mammary glands to produce breast milk. Lactation failure is found to be most common due to stress, caesarean (surgical) delivery, postpartum haemorrhage, maternal obesity, infection or illness with fever, diabetes, thyroid conditions, maternal smoking, some medications and herbal preparations, hormonal forms of birth control, especially any containing oestrogen. ${ }^{[1]}$

According to WHO, about 820000 child lives would be saved every year if breastfeeding scaled in Universal level. Under six month of age, only $40 \%$ of infants are taking exclusively breast feeding. ${ }^{[2]}$-To improve mother child bonding, skin to skin contact, breast feeding and rooming in is important. Childcare experts have long known that the closeness and intimacy of breastfeeding strengthens maternal affection. It releases the hormone called 
'Oxytocin' also known as a trust or cuddle hormone. This hormone helps to enhance mother's feelings of trust, love and affection and helps to reduce fear. ${ }^{[3]}$

To study the same, the researcher reviewed many literatures and it was obtained through various sources, printed as well as electronic which included CINHAL (Cumulative index TO Nursing \& Allied Health Literature), MEDLINE (Medical Literature Analysis \& Retrieval System Online), PubMed, ProQuest \& Google scholar.

\section{Material Methods And Findings:-}

By reviewing around 45 literatures, researchers could demarcate them into two subsections:

1. Effect of foot reflexology on lactation among postnatal women.

2. Effect of foot reflexology on other obstetric factors like anxiety, labor pain, post-operative pain, sleep, post csection fatigue, outcome of labor, intensity and duration of labor.

\begin{tabular}{|c|c|c|c|}
\hline $\begin{array}{l}\text { AUTHOR: } \\
\text { K. Loganayagi, } \\
\text { G. Sumathi } \\
\text { S. J. Nalini }{ }^{[4]} \\
\text { YEAR: } \\
2014 \\
\text { CONTRY: } \\
\text { India }\end{array}$ & $\begin{array}{l}\text { OBJECTIVE: To } \\
\text { assess the } \\
\text { effectiveness of } \\
\text { reflex zone therapy } \\
\text { on lactation among } \\
\text { primi para. }\end{array}$ & $\begin{array}{l}\text { METHODOLOGY: } \\
\text { experimental pre-test post-test } \\
\text { control group design was conducted } \\
\text { on total } 60 \text { samples ( } 30 \text { in each } \\
\text { group). Modified LATCH Breast } \\
\text { feeding assessment tool was used to } \\
\text { assess lactation. In intervention } \\
\text { group reflex zone therapy was given } \\
\text { for } 20 \text { minutes morning, afternoon } \\
\text { and evening for three consecutive } \\
\text { days along with routine care and } \\
\text { control group received only routine } \\
\text { care. }\end{array}$ & $\begin{array}{l}\text { RESULT: The post-test mean } \\
\text { of experimental group was } \\
30.40 \text { when compared to mean } \\
17.87 \text { of control group which } \\
\text { proved a statistical significance } \\
\text { at } p<0.001 \text {. } \\
\text { CONCLUSION: Reflex zone } \\
\text { therapy is a simple, innovative } \\
\text { and effective method for early } \\
\text { initiation of breast feeding } \\
\text { among primi mothers. }\end{array}$ \\
\hline $\begin{array}{l}\text { AUTHOR: } \\
\text { Mitra Savabi } \\
\text { Esfahani, } \\
\text { Shohreh Berenji- } \\
\text { Sooghe }{ }^{[5]} \\
\text { YEAR: } \\
2015 \\
\text { COUNTRY: } \\
\text { Iran }\end{array}$ & $\begin{array}{l}\text { OBJECTIVE: To } \\
\text { assess the effect of } \\
\text { acupressure on milk } \\
\text { volume } \\
\text { breastfeeding } \\
\text { mothers. }\end{array}$ & $\begin{array}{l}\text { METHODOLOGY: A randomized } \\
\text { clinical trial was conducted on } 60 \\
\text { breastfeeding mothers ( } 30 \text { in each } \\
\text { group). Routine education along } \\
\text { with bilateral acupressure was } \\
\text { performed for } 12 \text { consecutive days } \\
\text { on the acupoints of SI1, LI } 4 \text {, and } \\
\text { GB } 21 \text { in the intervention group, as } \\
\text { three sessions per week with each } \\
\text { session conducted } 2-5 \text { times. The } \\
\text { control group received only routine } \\
\text { education. In both groups, breast } \\
\text { milk volume before intervention and } \\
2 \text { and } 4 \text { weeks after intervention was } \\
\text { evaluated by an electric pump. }\end{array}$ & $\begin{array}{l}\text { RESULT: Mean volumes of } \\
\text { milk before and } 2 \text { and } 4 \text { weeks } \\
\text { after the intervention were } \\
10.5,33, \text { and } 36.2, \\
\text { respectively, in the acupressure } \\
\text { group and 9.5, 17.7, } 18 \\
\text { respectively in the control } \\
\text { group. ANOVA test showed a } \\
\text { significant difference in the } \\
\text { mean volume of milk at } 2 \text { and } \\
4 \text { weeks after the intervention } \\
\text { (P<0.001). } \\
\text { CONCLUSION Acupressure } \\
\text { is a good and effective method } \\
\text { of alternative medicine to } \\
\text { increase breastfeeding. }\end{array}$ \\
\hline $\begin{array}{l}\text { AUTHOR: } \\
\text { Dr. R. Danasu }{ }^{[6]} \\
\text { YEAR: } \\
2015 \\
\text { COUNTRY: } \\
\text { India }\end{array}$ & $\begin{array}{lr}\text { OBJECTIVE: } & \text { To } \\
\text { assess effectiveness } \\
\text { of reflex } r \text { zone } \\
\text { stimulation } & \text { on } \\
\text { initiation } & \text { and } \\
\text { maintenance } & \text { of } \\
\text { lactation } & \text { among } \\
\text { lactation } & \text { failure } \\
\text { mothers } & \end{array}$ & $\begin{array}{l}\text { METHODOLOGY: Qualitative } \\
\text { research study was conducted on } 60 \\
\text { postnatal lactation failure mothers. } \\
\text { The pre-test was conducted by using } \\
\text { the Modified breast feeding } \\
\text { assessment scale, then all the } \\
\text { samples were administered the } \\
\text { intervention of reflex zone } \\
\text { stimulation for five days. Post-test } \\
\text { was done after } 5^{\text {th }} \text { day. }\end{array}$ & $\begin{array}{l}\text { RESULT: Overall mean } \\
\text { difference value was 14.29. } \\
\text { The paired' t't' test overall value } \\
\text { of pre and post level } \\
\text { assessment of lactation was } \\
47.29 \text { which was statistically } \\
\text { highly significant at the level } \\
\text { of p<0.001. } \\
\text { CONCLUSION: Reflex zone } \\
\text { stimulation is effective in } \\
\text { initiation and maintenance of } \\
\text { lactation. }\end{array}$ \\
\hline
\end{tabular}




\begin{tabular}{|c|c|c|c|}
\hline $\begin{array}{l}\text { AUTHOR: } \\
\text { Atena } \\
\text { Mohammadpour, } \\
\text { Mahboubeh } \\
\text { Valiani, } \\
\text { Alireza Sadeghnia } \\
\text { [7] } \\
\text { YEAR: } \\
2015 \\
\text { COUNTRY: } \\
\text { Iran }\end{array}$ & $\begin{array}{l}\text { OBJECTIVE: To } \\
\text { investigate the effect } \\
\text { of reflexology on } \\
\text { the breast milk } \\
\text { volume of preterm } \\
\text { infant's mothers }\end{array}$ & $\begin{array}{l}\text { METHODOLOGY: The clinical } \\
\text { trial was conducted among } 50 \\
\text { mothers with premature infants ( } 25 \\
\text { mothers in each group). The } \\
\text { reflexology intervention was } \\
\text { performed for one session a day for } \\
6 \text { days. The control group received } \\
\text { regular breastfeeding training. In } \\
\text { both groups, mothers were asked to } \\
\text { collect milk themselves using an } \\
\text { electric breast pump and the volume } \\
\text { of milk collected in each session was } \\
\text { recorded. }\end{array}$ & $\begin{array}{l}\text { RESULT: Independent t-test } \\
\text { showed that the mean increase } \\
\text { in milk volume from day } 1 \text { to } \\
\text { day } 5 \text { after the intervention, } \\
\text { relative to before the } \\
\text { intervention, was significantly } \\
\text { higher in the reflexology group } \\
\text { compared to the control group } \\
(\mathrm{p}<0.05) \text {. } \\
\text { CONCLUSION: Reflexology } \\
\text { is effective on the volume of } \\
\text { milk of mothers and this low } \\
\text { cost and easy procedure can be } \\
\text { used along with regular } \\
\text { lactation training. }\end{array}$ \\
\hline $\begin{array}{l}\text { AUTHOR: } \\
\text { Mrs. L. Chitra }{ }^{[8]} \\
\text { YEAR: } \\
2014 \\
\text { COUNTRY: } \\
\text { India }\end{array}$ & $\begin{array}{lr}\text { OBJECTIVE: } & \text { To } \\
\text { assess effect } & \text { of } \\
\text { reflex } & \text { zone } \\
\text { stimulation ran } & \text { on } \\
\text { lactation among } \\
\text { post-caesarean } \\
\text { mothers }\end{array}$ & $\begin{array}{l}\text { METHODOLOGY: A quasi } \\
\text { experimental study was done on total } \\
26 \text { post caesarean mothers (13 in } \\
\text { each group). LATCH breastfeeding } \\
\text { assessment tool was used to assess } \\
\text { lactation. The intervention was } \\
\text { provided five hours after caesarean } \\
\text { section once daily for three days for } \\
\text { ten minutes. The LATCH score was } \\
\text { assessed before and after three } \\
\text { sessions of intervention. Control } \\
\text { group received routine assistance for } \\
\text { breastfeeding only. }\end{array}$ & $\begin{array}{l}\text { RESULT: The mean } \\
\text { difference of experimental and } \\
\text { control group was } 5.55 \text { and } \\
2.92 \text { respectively. In post-test } \\
\text { the calculated't' value in } \\
\text { experimental group was } 19.71 \\
\text { and for control group was } 9.59 \\
\text { with } 0.05 \text { level of significance. } \\
\text { CONCLUSION: Application } \\
\text { of reflex zone stimulation is } \\
\text { effective in initiation of breast } \\
\text { milk secretion and promotion } \\
\text { of breastfeeding. }\end{array}$ \\
\hline $\begin{array}{l}\text { AUTHOR: } \\
\text { Soheila Moghimi } \\
\text { Hanjani, } \\
\text { Zahra } \\
\text { Mehdizadeh } \\
\text { Tourzani, } \\
\text { Mahnaz Shoghi }{ }^{[9]} \\
\text { YEAR: } \\
2013 \\
\text { COUNTRY: } \\
\text { Iran }\end{array}$ & $\begin{array}{l}\text { OBJECTIVE: To } \\
\text { assess the effect of } \\
\text { foot reflexology on } \\
\text { Anxiety, Pain and } \\
\text { outcome of labor in } \\
\text { primigravida women }\end{array}$ & $\begin{array}{l}\text { METHODOLOGY: The clinical } \\
\text { trial study was conducted on } 80 \\
\text { primigravida mothers ( } 40 \text { in each } \\
\text { group). In intervention group, mild } \\
\text { massage of all feet sole and then } \\
\text { fixed or rotating pressure was } \\
\text { applied on pituitary gland (in center } \\
\text { of thumb), solar plexus (in second } \\
\text { and third toes) and uterus for } 40 \\
\text { minutes. In control group, routine } \\
\text { care and massage was performed. } \\
\text { The pain intensity was scored } \\
\text { immediately after the end of } \\
\text { intervention and at } 30,60 \text { and } 120 \\
\text { minutes based on McGill } \\
\text { Questionnaire for Pain Rating Index } \\
\text { (PRI) and Spielberger State Trait } \\
\text { Anxiety Inventory was completed } \\
\text { before and after intervention in both } \\
\text { groups. }\end{array}$ & $\begin{array}{l}\text { RESULT: The mean anxiety } \\
\text { score in first stage of labor } \\
\text { after intervention had in } \\
\text { intervention group had } \\
\text { significantly decreased. There } \\
\text { was no significant difference } \\
\text { with respect to mean pain } \\
\text { intensity score before and } \\
\text { immediately after intervention } \\
\text { in both groups (P>0.05) but } \\
\text { difference in half, one and two } \\
\text { hours after intervention was } \\
\text { statistically significant. } \\
\text { CONCLUSION: } \\
\text { reflexology is very effective } \\
\text { and non-invasive technique } \\
\text { which can be used to reduce } \\
\text { labor duration, pain, anxiety } \\
\text { and increase APGAR score of } \\
\text { new-born. }\end{array}$ \\
\hline $\begin{array}{l}\text { AUTHOR: } \\
\text { Morvarid Irani, } \\
\text { Masoumeh } \\
\text { Kordi }^{[10]}\end{array}$ & $\begin{array}{l}\text { OBJECTIVE: To } \\
\text { assess the effect of } \\
\text { hand and foot } \\
\text { massage on post- } \\
\text { caesarean pain and }\end{array}$ & $\begin{array}{l}\text { METHODOLOGY: The clinical } \\
\text { trial was performed on } 80 \text { pregnant } \\
\text { women ( } 40 \text { in each group). The } \\
\text { massage was performed for } 20 \\
\text { minutes on patient's extremities and }\end{array}$ & $\begin{array}{l}\text { RESULT: The levels of pain } \\
\text { and anxiety significantly } \\
\text { decreased in the intervention } \\
\text { group, immediately, } 60 \text { and } 90 \\
\text { minutes after the intervention }\end{array}$ \\
\hline
\end{tabular}




\begin{tabular}{|c|c|c|c|}
\hline $\begin{array}{l}\text { YEAR: } \\
2015 \\
\\
\text { COUNTRY: } \\
\text { Iran }\end{array}$ & anxiety. & $\begin{array}{l}\text { then the levels of pain and anxiety } \\
\text { were evaluated before the } \\
\text { intervention and immediately, } 60 \\
\text { and } 90 \text { minutes after the } \\
\text { intervention. In the control group, } \\
\text { the researcher went to the patients' } \\
\text { bedside for } 20 \text { minutes, and had an } \\
\text { informal chat with them. }\end{array}$ & $\begin{array}{l}(\mathrm{P}<0.001) \text {. } \\
\text { CONCLUSION: Hand and } \\
\text { foot massage can be used to } \\
\text { reduce pain and anxiety. }\end{array}$ \\
\hline $\begin{array}{l}\text { AUTHOR: } \\
\text { Deepshikha, } \\
\text { Vibha }^{[11]} \\
\text { YEAR: } \\
2016 \\
\text { COUNTRY: } \\
\text { India }\end{array}$ & $\begin{array}{l}\text { OBJECTIVE: To } \\
\text { assess effect of foot } \\
\text { reflexology on post- } \\
\text { operative pain and } \\
\text { sleep among post } \\
\text { caesarean mothers }\end{array}$ & $\begin{array}{l}\text { METHODOLOGY: A quantitative } \\
\text { quasi experimental non randomized } \\
\text { control group research design was } \\
\text { done on } 60 \text { post caesarean mothers } \\
\text { ( } 30 \text { in each group). Numerical rating } \\
\text { scale to assess level of pain and level } \\
\text { of sleep assessed by structured sleep } \\
\text { scale. Foot reflexology had been } \\
\text { provided to experimental group once } \\
\text { a day for } 3 \text { consecutive days from } \\
1 \text { st post-operative day for } 15 \text { minutes } \\
\text { and control group received routine } \\
\text { post-operative care. Post-test was } \\
\text { done on } 4{ }^{\text {th }} \text { day. }\end{array}$ & $\begin{array}{l}\text { RESULT: Post interventional } \\
\text { level of pain was found to be } \\
\text { significantly lower in the } \\
\text { experimental group (p<0.001) } \\
\text { than in the control group. The } \\
\text { post interventional level of } \\
\text { sleep of an experimental group } \\
\text { was found to be improved } \\
(\mathrm{p}<0.001) \text { compared with pre- } \\
\text { intervention. } \\
\text { CONCLUSION: } \\
\text { reflexology is a noot } \\
\text { pharmacological, cost effective } \\
\text { and simple intervention } \\
\text { without any adverse effects. It } \\
\text { was also effective in reducing } \\
\text { the level of post-operative pain } \\
\text { and improving sleep. }\end{array}$ \\
\hline $\begin{array}{l}\text { AUTHOR: } \\
\text { Fareideh Bastani, } \\
\text { Elaheh Rouhi } \\
\text { Rahim Begloo }{ }^{[12]} \\
\text { YEAR: } \\
2012 \\
\text { COUNTRY: } \\
\text { Iran }\end{array}$ & $\begin{array}{l}\text { OBJECTIVE: To } \\
\text { assess effectiveness } \\
\text { of foot reflexology } \\
\text { on maternal post c- } \\
\text { section fatigue }\end{array}$ & $\begin{array}{l}\text { METHODOLOGY: } \\
\text { randomized clinical trial was } \\
\text { conducted on } 99 \text { mothers having } \\
\text { caesarean section, were divided into } \\
\text { three groups of } 33 \text {. Foot reflexology } \\
\text { and leg massage were performed on } \\
\text { patients in the intervention ( } 40 \\
\text { minutes) and placebo groups, } \\
\text { respectively. The patients in the } \\
\text { control group received the common } \\
\text { post C-section care. }\end{array}$ & $\begin{array}{l}\text { RESULT: The mean scores of } \\
\text { fatigue severity in the } \\
\text { experimental and placebo } \\
\text { groups were significantly lower } \\
\text { than the control group } \\
(\mathrm{P}<0 / 001) \text { after intervention. } \\
\text { The comparative analysis of } \\
\text { mean fatigue scores, between } \\
\text { the experimental (23/2 } \pm 23 / 4) \\
\text { and placebo groups } \\
(11 / 7 \pm 13 / 1) \text {, indicated that the } \\
\text { reflexology intervention was } \\
\text { more effective in reducing } \\
\text { fatigue. } \\
\text { CONCLUSION: Reflexology } \\
\text { intervention was more effective } \\
\text { in reducing fatigue. }\end{array}$ \\
\hline
\end{tabular}

\section{Conclusion:-}

After reviewing various literatures, researcher found that majority of mothers who received the foot reflexology improved lactation. Foot reflexology is also effective for reducing anxiety, pain, outcome of labor and improve quality of sleep. Researchers observed that at different setups of India, studies related to effect of foot reflexology on lactation was done but same was not found much to based on researcher's area of interest. Hence, through this literature review the researchers wish to conduct a research in own preferred setup.

\section{Conflict of interest:}

None 


\section{Source of funding:}

Self

\section{Ethical clearance:}

Permission was obtained from concerned Authorities.

\section{References:-}

1. Standford Children's Health. Delayed or Not Enough Milk Production. 2019. Available form: https://www.stanfordchildrens.org/en/topic/default?id=delayed-or-not-enough-milk-production-90-P02390

2. WHO [World Health Organization]. 10 facts on breastfeeding [Internet]. August 2017. Available from: http://www.who.int/features/factfiles/breastfeeding/en/

3. David Derbyshire. Breast feeding does help mothers bond with babies- because it release the 'love hormone'. July 18 2008. Available form: https://www.dailymail.co.uk/health/article-1036151/Breast-feeding-DOES-helpmothers-bond-babies--releases-love-hormone.html

4. K. Loganayagi, G. Sumathi. Journal of science. Effectiveness of reflex zone therapy among primi para at selected hospitals. 2014. Volume 4. Available form : www.journalofscience.net/doi/MTY0a2FsYWkxNDc4NTIzNjk=

5. Mitra Savabi Esfahani. Iranian journal of nursing and midwifery research. Effect of acupressure on milk volume of breastfeeding mothers. Jan-Feb 2015. Volume 20(1). Available form: https://www.ncbi.nlm.nih.gov/pmc/articles/PMC4325417/

6. Dr. R Danasu. Asian journal of Nursing education and research. Effectiveness of Reflex Zone Stimulation on initiation and maintenance of Lactation among Lactation Failure Mothers. 2015. Volume 5. Available form : http://ajner.com/HTMLPaper.aspx?Journal=Asian\%20Journal\%20of\%20Nursing\%20Education\%20and\%20Re search;PID=2015-5-4-14

7. Atena Mahommadpour, Mahboubeh Valiani. Iranian Journal of Nursing And Midwifery Research. Investigating the Effect of Reflexology on the Breast Milk Volume of Preterm Infants' Mothers. 2018. Available form: https://www.ncbi.nlm.nih.gov/pmc/articles/PMC6111660/

8. Mrs. L. Chitra. Effect of reflex zone stimulation on lactation among post-caesarean mothers. 2014. Available form: http://repositorytnmgrmu.ac.in/6293/1/300303414deepthi.pdf

9. Soheila Moghimi Hanjani, Zahra Mehdizadeh Tourzani. Tehran university of medical science. The Effect of Foot Reflexology on Anxiety, Pain, and Outcomes of the Labor in Primigravida Women. June 16, 2014. Available form : http://acta.tums.ac.ir/index.php/acta/article/view/4277/4684

10. Morvarid Irani, Masoumeh Kordi. Journal of midwifery \& reproductive health. The effect of foot and hand massage on post caesarean pain and anxiety. November 2015. Available form: http://jmrh.mums.ac.ir/article_4856_596bad7a9edbf7ea63236dc0bf349e14.pdf

11. Deepshikha. International Journal of Nursing Education and Research. Effect of foot reflexology on postoperative pain and sleep among post caesarean mothers. Published in 2016. Volume 4. Available form: http://ijneronline.com/HTMLPaper.aspx?Journal=International\%20Journal\%20of\%20Nursing\%20Education\%2 0and\%20Research;PID=2016-4-4-10

12. Fareideh Bastani. Evidence Based Care Journal. Effectiveness of Foot Reflexology on Maternal Post C-Section Fatigue. 2015. Available form: http://ebcj.mums.ac.ir/article_4949.html. 